\title{
Untold stories: Male child sexual abusers' accounts of telling and not telling about sexual abuse experienced in childhood
}

Dr Susan Roberts (ORCiD: 0000-0002-3050-415x)

Senior Lecturer in Criminology

Hillary Rodham Clinton School of Law

Swansea University

S.m.roberts@swansea.ac.uk

Tel: 01792513352 
Male child sexual abusers telling and not telling of sexual abuse experienced in childhood

\begin{abstract}
With evidence suggesting that females are more likely to be victims of child sexual abuse (CSA), much of the literature - including that on disclosure - focuses on females. Thus, male victims remain "under-studied" (Ressel et al., 2018, p.239). Given this, the aim here is to contribute to the scant knowledge base on the sexual abuse of males and disclosure by focusing on males whose voices are even more rarely heard than those in the general male population: those who have perpetrated CSA. The men whose stories are told here had been convicted of, and imprisoned for, CSA in the United Kingdom (UK). They were part of a sample of 101 incarcerated males, 40 of whom reported at interview that they had been sexually abused in childhood. Eighteen of those 40 men are focused on here as they provided some detail as to whether they had disclosed that abuse in childhood or adulthood, the responses they had received, and also why they had not disclosed. Their narratives shed some much-needed light on the nature of sexual abuse experienced by males, its onset and duration, sexual re-victimization, relationships with perpetrators, the diverse nature of disclosure, the extent to which victims disclose and when, the responses received, and why they do not tell. Little is known of these aspects of male CSA (Easton, 2013; Ressel et al., 2018). The implications of the findings are considered together with future research directions.
\end{abstract}

\title{
Key words
}

Children, Sexual Abuse Disclosure, Sexual Abuse, Victim, Offender/Perpetrator, Males, Gender Issues 
Male child sexual abusers telling and not telling of sexual abuse experienced in childhood

Child sexual abuse (CSA) is a global problem (Reitsema \& Grietens, 2016), affecting significant numbers of children and young people (World Health Organization, 2017). Many adults report never having disclosed abuse during childhood, and it is suspected that many never disclose at all (O’Leary, Coohey, \& Easton, 2010). The literature on disclosure has focused mainly on female victims (McGregor, Julich, Glover, \& Gautam, 2010). Although evidence suggests that 1 in 6 males have experienced CSA (Romano, Moorman, Ressel, \& Lyons, 2019), less attention has been paid to male survivors (Easton, 2013), the "characteristics" of their abuse (Ressel, Lyons, \& Romano, 2018, p.239), the extent to which they disclose abuse, and responses to that (Easton, Saltzman, \& Willis, 2014). Here, the focus is on males who are even less visible in research on this topic: those who have been convicted of, and imprisoned for CSA, and who report experiencing sexual abuse in childhood. Higher rates of CSA are more apparent in the backgrounds of sexual offenders - and, in particular, child sexual abusers - than in the general male population (Jespersen, Lalumiere, \& Seto, 2009). Yet, limited attention has been paid to the opportunity to learn from offenders themselves about their experiences of abuse, and in particular, their disclosure experiences. Indeed, as Plummer (1995, p.118) notes, this is a population whose "own story in their own voice is not heard", in part, because "nobody will allow it to be told and nobody wishes to hear". Yet, they are often victims too and their stories - like those of other male survivors can shed much-needed light on CSA and factors which both prompt and inhibit disclosure, and contribute to more effective intervention with both victims and perpetrators.

In an attempt to more fully understand the "dynamics of the disclosure process" (Reitsema \& Grietens, 2016, p.336) in relation to sexual offenders, the men's accounts of disclosing abuse, the responses received, and their reasons for not telling, are presented here. The aim is to tease out differences in those accounts, with specific reference to the gender of the perpetrator, and contrasting life stages - childhood and adulthood - and to contribute to a 
Male child sexual abusers telling and not telling of sexual abuse experienced in childhood

knowledge base in which often, such accounts are not differentiated. Indeed, this approach is in contrast with previous research which has tended to mask differences and compound understanding of this "unique" and individual process (Lovett, 2004, p.355). The terms telling and not telling are employed here, as they represent the language used by the men at interview in their reflection on disclosure and non-disclosure.

\section{Telling and not telling about CSA}

Disclosure is defined as telling about CSA on a formal or informal level, on a voluntary basis, or as a consequence of others' prompting (Ullman, 2003). Child protection agencies place much emphasis on the need to tell as soon as possible (Alaggia, 2004), so that victims are safeguarded and offenders detected (McElvaney, 2015). Yet, the potential for non-supportive responses to disclosure to impact negatively on victims (Fontes \& Plummer, 2010) should also be acknowledged, for some report not being believed, or that their situation worsened following telling (Barter, 2003). For others, abuse continued following its exposure (Jonzon \& Lindblad, 2004), with family conflict emerging (Staller \& Nelson-Gardell, 2006). Not telling also comes at a cost, however, given the effort required to keep the secret (Staller \& Nelson-Gardell, 2006).

Disclosure of CSA is a "complex process" (Priebe \& Svedin 2008, p.1095). Yet, this is rarely acknowledged. There has been an increased research emphasis on disclosure, albeit as it relates to female victims (Jonzon \& Lindblad, 2004; McGregor et al., 2010). Some have focused on forms of disclosure, for example, accidental and purposeful (Sgroi, 1982). Others, on the stages children pass through during the process of disclosure (Staller \& NelsonGardell, 2006), factors which influence children to self-disclose (Paine \& Hansen, 2002), children's perspectives and the context for disclosure (Jensen, Gulbrandsen, Mossige, 
Male child sexual abusers telling and not telling of sexual abuse experienced in childhood

Reichelt, \& Tjersland, 2005), adult disclosure (Tener \& Murphy, 2015), variables associated with delay of disclosure (Goodman-Brown, Edelstein, Goodman, Jones, \& Gordon, 2003; McElvaney, 2015), the response of health professionals (McGregor et al., 2010), maternal response (Hunter, 2015), cultural (Gilligan \& Akhtar, 2006) and individual, relational and social factors which inhibit disclosure (Collin-Vezina, De La Sablonniere-Griffin, Palmer \& Milne, 2015), and the needs of caregivers following disclosure (van Toledo \& Seymour, 2016).

Disclosure is facilitated where there is anger towards the perpetrator (Fontes \& Plummer, 2010), when victims are older, the abuse is extra-familial - perpetrated "outside family settings" (Smallbone \& Wortley, 2001, p.2), there is a positive relationship with parents (Priebe \& Svedin, 2008), or a geographical distance between victim and perpetrator (Hunter, 2011). Many CSA victims, however, do not disclose due to guilt and shame, fear of their abuser, fear of not being believed, or a mistrust of professionals (Alaggia, 2004). Intrafamilial abuse - perpetrated by those related to their victim/s, or living with them (Smallbone \& Wortley, 2001) - is likely to result in delayed disclosure due to the close relationship between abuser and victim (Smith, Dogaru, \& Ellis, 2015), and victims' fears as to the consequences for family (Allnock, 2010). Children with disabilities are less likely to disclose (Children's Commissioner for England, 2015), as are children abused by educators (Roberts \& Vanstone, 2014), and others in positions of trust (Colton, Roberts \& Vanstone, 2012).

\section{Disclosure and male victims}

Boys are more likely than girls to be abused by males (McGuffey, 2008), by a non-family member, and those in a position of trust (Ogloff, Cutajar, Mann, \& Mullen, 2012), and in conjunction with other children (Finkelhor, 1984). They are also more likely to experience 
Male child sexual abusers telling and not telling of sexual abuse experienced in childhood

physical maltreatment (Finkelhor, 1984). Their sexual abuse tends to be severe (Spiegel, 2003), beginning at an early age, persisting for some time, and characterised by penetration (Ressel et al., 2018). The stigma attached to being a male victim of CSA (Easton et al., 2014) and the "male ethic", of self-reliance appear to feature in the minimisation and underreporting of sexual abuse of males (Finkelhor, 1984, p.152). Males are less likely to disclose CSA than females (O'Leary \& Barber, 2008), more likely to be held responsible for their own abuse, and viewed negatively if they do disclose (Spiegel, 2003). While there is a considerable body of evidence on disclosure, less attention has been paid specifically to males. Those who have focused on males have explored the barriers to disclosure (Easton et al., 2014; Sorsoli, Kia-Keating, \& Grossman, 2008), disclosure experiences and responses (Easton, 2013; Gagnier \& Collin-Vezina, 2016), the impact of disclosure on men abused by Catholic priests (Isely, Isely, Freiburger, \& McMackin, 2008), and on mental health (Romano et al., 2019). Yet others have examined the shame and guilt arising from disclosure (Dorahy \& Clearwater, 2012), and the impact of perceptions of men and masculinity on disclosure (Anderson, 2011).

While disclosure presents challenges for all victims, it appears that the taboo associated with female sexual offending (FSO) further constricts telling (Denov, 2004). For males, societal norms which endorse older woman/younger boy relationships (Hunter, 1990) inhibit disclosure. Thus, cases involving adult females and adolescent boys may remain hidden because of the tendency to view them as an initiation (Elliott, 1993) into the realms of sexual activity, or a rite of passage (Mellor \& Deering, 2010).

\section{Methodology}

Participants 
Male child sexual abusers telling and not telling of sexual abuse experienced in childhood

A phenomenological approach (Bryman, 2008) was adopted in order to elicit a detailed account of the lived experiences (Garrett, 2010) of abusive men. Purposive sampling (Bryman, 2008) was employed, and the prison database - which included details of prisoners and their offences - was used as a sampling frame. The 18 men focused on here were part of a larger sample of 101 males who had been convicted of, and imprisoned for, CSA in the UK. Forty of those 101 reported at interview that they had been sexually abused in childhood. Eighteen of those 40 provided some detail on telling and not telling about the CSA they had experienced, and are thus the focus of discussion here. The men ranged in age from 23 to 67 . In total, 6 out of the 18 men had experienced sexual re-victimization: only one of those 6 had disclosed all the abuse he had experienced, (and one man disclosed none). Thus, taken together, the numbers referred to in Tables 1 and 2 amount to more than 18, as 4 men appear under the category "disclosing CSA", and also "not telling". Tables 1 and 2 provide details of the abuse experienced by participants, whether/when they disclosed, who they disclosed to, and why they did not tell.

Tables 1 and 2 near here

\section{Ethics}

Ethical approval for the study was granted by the Centre for Criminal Justice and Criminology Ethics Committee at Swansea University. Given the nature of the research, much emphasis was placed on establishing trust at the outset. A covering letter detailing the research aims and objectives was distributed to prisoners through staff on the prison wings. A considerable amount of time was then spent communicating directly with prisoners, responding to queries about the purpose of the research, the extent to which confidentiality and anonymity could be assured, how and where data would be held, who would have access to the findings, and how they would be used. The limitations of confidentiality were made clear at the outset, namely, that should information be disclosed at interview that might result 
Male child sexual abusers telling and not telling of sexual abuse experienced in childhood

in harm to an individual or in relation to additional offences, that information would be passed on to prison staff.

\section{Data collection}

Every effort was made to ensure the trustworthiness of the research (Lincoln \& Guba, 1985), with regard to data collection, analysis, and presentation of the findings, with emphasis firmly placed on the voice of participants, as opposed to the perspective of the researcher. Individual interviews were undertaken at a prison in the UK. They lasted between one and 3 hours, were tape-recorded and fully transcribed. A semi-structured questionnaire facilitated the collection of data on the men's offending and childhood. All were asked: "Can you tell me about the nature of your offence/s [against children]?" and "What was your relationship with your victim/s?" As a means of ensuring validity, information on the men's offending held in the prison data base was cross-checked with that provided at interview. The men's accounts were consistent with the records held. Questions focusing on their childhood allowed the men the opportunity to "speak freely" about that (Oaksford \& Frude, 2003, p.68), in order that "individual" stories of abuse emerged (Dodsworth, 2014, p.189). All were asked: "Can you tell me whether you were sexually abused as a child?", and if so, "By whom"? The question: “Can you tell me more about that?" enabled reflection on the nature and extent of the abuse. On disclosure, the men were asked: "Did you tell anyone about the abuse"?, and if so, "Who"? and "When"? If they had not disclosed, they were asked "Why"?, in an attempt to understand the barriers they encountered in that. They were also asked whether they had experienced any other abuse in childhood: "Were you physically abused as a child"?, and if so, "By whom"?, in order that as much information as possible could be obtained about their early lives, which evidence suggests are often characterised by physical violence (Craissati, McClurg, \& Browne, 2002). 
Male child sexual abusers telling and not telling of sexual abuse experienced in childhood

\section{Data analysis}

An inductive approach was adopted enabling "codes and themes to be derived from the content of the data themselves" (Lambie \& Johnston, 2016, p.902). In the first instance, reading through the interview transcripts several times enabled immersion in the data and an understanding of "commonalities and differences" (Miles \& Huberman, 1994, p.9). Data analysis involved 3 stages: open coding enabled the identification of broad themes in the interview transcripts relating to offenders' childhoods. More detailed axial coding resulted in the identification of key themes relating to CSA, and selective coding focused attention on those codes of most relevance (Strauss, 1987): telling and not telling about CSA, with a further set of sub-themes also evident. Under telling of CSA, sub-themes relating to responses and the impact of those emerged. Under not telling, sub-themes relating to the factors which inhibited telling during childhood, in both intra-and extra-familial contexts, were evident including, for example, fear. The Results are ordered according to these key themes, with the use of direct quotes placing emphasis on the realities of participants' stories (Lincoln \& Guba, 1985). All the men whose stories are told here were allocated pseudonyms, in order to ensure anonymity. A more detailed account of Methodology may be found elsewhere (see Roberts, 2017).

\section{Results}

The focus first is on the men who disclosed in childhood and responses to that, with specific reference to the gender of the perpetrator.

\section{Telling in childhood and responses: Experiencing male-perpetrated CSA}

\section{Not believed}

Alan's childhood was characterised by violence. He told his father of the abuse perpetrated by his friend, who: "used to visit [the family] every weekend", but recalled: "he [father] didn't believe me". Brian was re-victimized in childhood by 2 different males, and disclosed each abusive experience. He first told his mother about the abuse perpetrated by a neighbour but was not believed and was admonished for telling: 
Male child sexual abusers telling and not telling of sexual abuse experienced in childhood

That evening [immediately after the abuse] I told my mother and I was sent to bed because she said, neighbours don't do things like that and I mustn't say anything like

that. In those days, being a widow was hard for my mother, a single lady with children and she didn't want no upsets. I wasn't believed and I went to bed quite upset.

\section{Colluding to silence}

Brian also disclosed abuse perpetrated against him while on work experience, but he was again silenced: "I reported it to the hotel management...but they asked me not to report it to anyone else. That's another one that got away with it". Francis was first abused by his brother and then, by a youth worker. He provided no detail on the latter, however, and had not disclosed it. He had been sexually abused by his brother from the age of 12 to 15 years and disclosed the abuse to his parents, however, attempts were made to contain that disclosure within the family: "I told my parents about it and they had a word with him and that was it. It was still kept in the family. But nothing happened about it. My sister, everybody [in the family] knew about it. It was like, it's all in the family - keep it quiet”. Francis found his parents' response lacking: "it wasn't enough", and sadly, the abuse did not stop as a result of their "intervention". This resulted in Francis running away from home on several occasions.

\section{Denial and a failure to protect}

Oliver had been abused by a family friend, his brother, and also while in residential care. He was abused by the man who moved into the family home after his father's death, over a period of 2 years. He believed his mother was aware of what was happening from the outset, in spite of her denial. Oliver recalled that when he told, his mother did nothing to protect him, and how he "hated" her for that: "I started to hate my mother. I thought she knew what was 
Male child sexual abusers telling and not telling of sexual abuse experienced in childhood

going on with this bloke living in that was abusing us but she denied it. Then she admitted it a couple of years ago. She admitted that she knew but she was too scared, swept it under the carpet".

Frank had been sexually abused in institutional care by his "headmaster" (he had also been abused by his schoolfriend's mother - abuse he did not disclose), and recalled the response of staff to his disclosure of the former. The extent of his pain and discomfort was dismissed, and he felt further humiliated by his peers' response. In the face of such denial of harm, he felt that his only option was to run away:

Well apparently, it happened to a lot of boys there. You would get picked to go into a special room, which you thought you were having a privilege. Only he [headmaster] would come in the night then and jump into bed with you. We was in dormitories and there was these two rooms then - that was if you had special privileges - but that was for his privileges. I stuck it for a week after it was happening - it happened 3 times and then I run away from there. He [headmaster] put his penis up my backside 3 times. The first time, I had to go to the nurse because I was bleeding but it was a male nurse and all I got was a bit of cream. They knew what was going on but nothing was being done about it. And, of course, the other boys would be sniggering then. They would see you coming from the nurse and the way that you was walking, so they knew what was happening to you. It didn't happen the second night but the third and fourth night it did and then, by the end of the week, I had run away from there.

\section{Punishment and further abuse}

In spite of the unsupportive response from his mother in relation to the abuse perpetrated by a family friend, Oliver later disclosed the abuse he experienced in residential care. However, he 
Male child sexual abusers telling and not telling of sexual abuse experienced in childhood

was punished and re-abused for telling, and made clear how that impacted on his sense of feeling "safe":

I told [welfare staff] when I was 13 years of age and got a good hiding for it in the children's home. I got a good caning and locked in my room. I was pinned down and put into a room and stripped naked. You think to yourself, it must be alright to have sex with blokes. As a child it was my experience. Telling somebody? No, you get a good hiding for it. You don't tell anybody again do you? It were 20 years later [that he next spoke of the abuse, to staff while in prison] - even then I didn't think it was safe.

Oliver chose not to discuss the sibling abuse he had experienced but did not disclose.

\section{Telling in childhood and responses: Experiencing female-perpetrated CSA}

\section{Abuse minimized}

Only one of the 4 men who experienced female-perpetrated CSA disclosed that: Andrew. He told both his parents independently of the abuse by his grandmother, and there is evidence of the minimization of the abuse in their unsupportive responses:

At 10 my grandmother started molesting me. I told my mother but she turned a blind eye and said, "nan's lonely, don't be silly, nan loves you very much". The abuse continued until I started work and then I realised it was wrong after talking to workmates about sex. I mentioned it to my father who was very rarely around and he just smiled. Both parents knew and ignored it.

Unfortunately, the abuse progressed in severity following Andrew's disclosure, escalating from touching under clothing to penetrative sexual activity, and persisting over several years.

\section{Not telling in childhood: Experiencing male-perpetrated CSA}


Male child sexual abusers telling and not telling of sexual abuse experienced in childhood

Next, the focus is on the men's accounts of not telling of their abuse in childhood.

\section{Fearfor own safety}

Neil did not disclose the abuse he experienced from his uncle from the age of "7 or 8 " due to a sense of fear: "No, [I was] too frightened [to tell]. There was no way". Like Neil, Ellis had been raped by his uncle from the age of 7 . The abuse lasted until he was 10 , and threats ensured he did not tell until he was imprisoned: "He [uncle] threatened me not to tell anyone. I never told anyone, only the priest in here". Donald was sexually abused by his father from the age of 5. His father had also engaged in alcohol misuse, physically abused him, and was sexually violent towards his mother. Such an environment presented little opportunity for Donald to tell of his abuse. He recalled how home was not a place of safety, and that his mother "wasn't there when I needed her". Due to his sense of isolation, he "constantly" ran away: "I did not have many friends as a child. We were very isolated. I was constantly running away from home".

Steven was sexually abused from the age of 11 to 16 - along with other children - by multiple perpetrators, many of whom were respected members of his community. For Steven, fear inhibited telling. He was fearful his mother would not have the capacity to protect him given her poor mental health, and also that as his abusers were his father's friends, this would compound his situation. Steven believed telling was likely to fuel his father's violent disposition and impact on his physical safety: "[I] couldn't tell my mother because she was highly strung. If she had told my father he would have beat me because it was his mates".

\section{Fear of not being believed}

Steven also recalled another barrier to telling: being consistently told by his abusers that he and the other children being abused would not be believed, and that the abuse was a punishment for bad behaviour: "One of the men said: nobody is going to believe you if you 
Male child sexual abusers telling and not telling of sexual abuse experienced in childhood

tell. When they abused us they would tell us they were punishing us for being naughty lads". John had been abused while in residential care, and also by his brother. He had disclosed neither but did not wish to provide any detail on the sibling abuse he experienced. Fear of not being believed suppressed telling of the abuse John experienced in care: "My house father used to come out of his flat at night and take boys to his flat. Now, it was our word against his and we never spoke up. We couldn't speak out because nobody believed us".

\section{Shame}

Barry had been raped by 3 young males while in youth custody. He recalled the violent nature of the abuse, and the resulting physical evidence of that. However, the sense of shame he felt at being a male victim was demonstrated in his reluctance to discuss the rape in any further detail, as he had not previously disclosed it: "I'm not going into detail. They don't know in here [prison]".

\section{Positive aspects of relationship with abuser}

Two men recalled positive aspects of their relationship with their abuser which inhibited telling until adulthood. Having been sexually abused by a male roomer from the age of 8 until he was "about 11", William was prepared to tolerate the "pain" of abuse because he enjoyed "going fishing" with his abuser, and was reluctant to relinquish that pleasure: "I used to like going fishing with him and in my mind I thought that if I told anyone there wouldn't be anyone to take me fishing again. I never said a word to anybody. The only time I mentioned that was when I was in prison". Bob had been abused by 2 different males in childhood, a neighbour and later, a youth worker but had only disclosed the abuse perpetrated by the former, since being imprisoned: 
Male child sexual abusers telling and not telling of sexual abuse experienced in childhood

He [the neighbour] abused me for 4 years, from when I was 7 to 11 . He was a friend of the family. It started by him taking me to work with him during the holidays. Dad was at work and mum was busy so they were grateful of the help. He told me I was special and his favourite and one day he started to fondle me. From the age of 8 he started to bugger me till we moved away, when it ended.

Like William, Bob welcomed the attention he received from his abuser and had not previously "acknowledged" the abuse as an "issue": "My family are only recently aware of the abuse since I came into prison. I had never acknowledged it as an issue in my life previously". Edward had been abused by a family friend, and Luke by a family member whose identity he did not wish to divulge. Both had disclosed as adults to prison staff but were reluctant to discuss that or any other aspects of their abuse at interview.

\section{Not telling in childhood: Experiencing female-perpetrated CSA}

Fear of the consequences for family

Bill had not disclosed the abuse perpetrated by his mother: "from as early as [I] can remember". In his case, not telling was related to fear of the consequences for his family: "I haven't said anything to anyone about it before, and I wouldn't want to take it any further. Do you know what I mean? I wouldn't want to take it to court or anything like that. I don't see the point in that - it would be too destructive for everybody".

\section{Sense of isolation}

Gareth had been abused by his older sister from the age of 11 . Although he was part of a large family, non-disclosure of that abuse appears to have been due, in part, to his sense of isolation. When asked at interview whether he had ever told anyone of the abuse he had 
Male child sexual abusers telling and not telling of sexual abuse experienced in childhood

experienced, Gareth replied: “Who could I tell? I weren't close enough to anyone to tell them".

\section{Abuse as a rite of passage}

Although Frank disclosed the male-perpetrated abuse he experienced, he had not told of the abuse by his schoolfriend's mother at the age of 12 . This, he recalled, was because he viewed the latter with a mixture of fear and excitement; and as a "part of growing up": "When I look back now, I think that maybe it was a part of growing up. But then you know, I was afraid in one way but excited in another".

\section{Discussion}

Child sexual abuse can have "a significant impact on the lives of victims and survivors" (CCE, 2015, p.12). However, with evidence suggesting females are more likely to be victims of CSA, male victims remain "under-studied" (Ressel et al., 2018, p.239). The aim here has been to contribute to the knowledge base on the sexual abuse of males and disclosure - and to more effective intervention - by focusing on a population of males whose voices are even more rarely heard: those who have perpetrated CSA. Here, we learnt of the nature of abuse experienced, its onset and duration, the relationship with perpetrators, sexual re-victimization, the extent to which males disclose and when, responses to disclosure and why males do not tell. Little is known of these aspects of the sexual abuse of males (Easton, 2013; Ressel et al., 2018). Although the sample is small, the findings illustrate the diverse nature of abuse and its disclosure, with perpetrators being male, female, siblings, and those in positions of trust and some experiences characterised by multiple perpetrators and re-victimization. Many of the men whose stories are told did not feel able to disclose their abuse in childhood due to a range of barriers which inhibited telling. For all those who did tell, the response received was 
Male child sexual abusers telling and not telling of sexual abuse experienced in childhood

unsupportive. Such responses may inhibit further disclosure, lead to distress and isolation (Donalek, 2001), and also distrust of others (Isely et al., 2008). The impact of this should not be under-estimated.

For those men abused by males, there were a number of barriers to telling which are also evident in the accounts of male and female victims in the general population: namely, fear for their own safety, and of not being believed (Alaggia, 2004). Moreover, the sense of shame (Dorahy \& Clearwater, 2012), "pervasive secrecy" (Summit, 1983, p.181), and concealment (Spiegel, 2003) demonstrated in one man's reluctance to discuss the rape he experienced, also emerges in the accounts of males who are not abusers. Males are less likely to perceive sexual activity with their perpetrator as abuse (Spiegel, 2003). For Mendel (1995), societal myths contribute to the misunderstanding that males have the strength and capacity to protect themselves from sexual harm, and are more likely to abuse others than become victims themselves. Also influential in the under-reporting and under-recognition of the sexual abuse of males, is the belief that males' sexual appetite renders them "willing and eager" to engage in sexual activity. The corollary is that any form of such activity is not abusive but rather, is "welcomed" by the male (Mendel, 1995, p.18). This features particularly in social constructions of young males' sexual activity with older females as a positive "encounter" (Spiegel 2003, p.12).

Some of the men's accounts demonstrate the complex nature of the relationship between victim and abuser, and the extent to which positive aspects of that relationship which are not sexual in nature but are "emotionally meaningful" to the child - suppress disclosure (Reitsema \& Grietens, 2016, p.333). Disclosing abuse is a complex, painful process which is unique to each victim (Durham, 2003). Acceptance of "limited social scripts" (Tener \& Murphy, 2015, p.395) where males present as perpetrators but not victims, and where females are victims but not perpetrators (Sorsoli et al., 2008), compound 
Male child sexual abusers telling and not telling of sexual abuse experienced in childhood

disclosure. It is unsurprising, therefore, that only 1 of the 4 men who reported femaleperpetrated CSA, disclosed in childhood. As was the case in Denov's (2003) research, the parental response was the minimization of that abuse. Consistent with other research, those who were abused by females recalled not telling of that due to: fear of the consequences for their family (Finkelhor, 1986), a sense of isolation (Deering \& Mellor, 2011), and a perception of the abuse as a rite of passage (Mellor \& Deering, 2010).

While there is some evidence in the literature of positive experiences of disclosure by males (Gagnier \& Collin-Vezina, 2016), all the men in this study who did tell of the abuse they experienced received unsupportive responses, including not being believed, collusion by others to ensure silence, denial of the abuse, and a failure to protect. For those in residential care, punishment and further abuse, and dismissal and humiliation resulted. For Reitsema and Grietens (2016, p.331): "Cultural values and beliefs, family characteristics, and family dynamics not only play a role in the etiology and maintenance of sexual abuse but may also affect the disclosure process". The men's narratives shed some light on this. In some cases, a violent and dysfunctional family environment, a mother's incapacity to protect and a "fragile social network" resulted in "general feelings of being unsafe" (Collin-Vezina, De la Sablonniere, Palmer, \& Milne, 2015, pp.129-130). Moreover, a patriarchal family structure (Fontes \& Plummer, 2010) where the mother was disempowered by a dominant male and the use of violence (Alaggia \& Kirshenbaum, 2005), appeared to contribute to a sense of isolation and also inhibited telling.

Mothers are less likely to be supportive if the alleged abuser is their partner, or they have a dependent or intimate relationship with them (Pintello \& Zuravin, 2001). Fear of the abuser, together with some concern as to what might be lost on an economic and emotional level, appear to have played a part here in some mothers' decisions not to believe and support their child. Where disclosure is made in childhood, victims' aims are often to protect 
Male child sexual abusers telling and not telling of sexual abuse experienced in childhood

themselves and end the abuse (Tener \& Murphy, 2015). Unfortunately, consistent with other findings on the outcome of disclosure (Smith et al., 2015), telling did not always result in the abuse ending for the men in this study. Moreover, an element of containment appears to characterize some of their experiences of telling. In one man's disclosure of sibling abuse there is evidence of the "damage and risks" associated with an attempt to negotiate "private solutions" to the discovery of abuse (Finkelhor, Williams \& Burns, 1988, p.113). Sibling abuse is the most prevalent and hidden form of intra-familial abuse (Stathopoulos, 2012). It will remain undetected if families attempt to manage the problem themselves (Hackett \& Masson, 2006) by "silencing" victims (CCE 2015, p.13), and both victims and perpetrators will be denied appropriate support.

Consistent with other research on the sexual abuse of males, the abuse experienced by the men in this study was often severe and protracted - in many cases involving penetration and began at an early age (Ressel et al., 2018). Some were abused together with other children or were aware of others being abused, for example, in residential care, and in some cases family life was also characterised by physical violence (Finkelhor, 1984). Childhood did not offer a place of safety for these men, and there was little opportunity for some to tell of their abuse (Jensen et al., 2005). Their narratives are often distinguished by a sense of feeling isolated and unsafe, and betrayal and powerlessness (Finkelhor \& Browne, 1985). In some, there is evidence of betrayal by those in a position to protect. In others, powerlessness and helplessness (Summit, 1983) feature, in their recognition of their own vulnerability and the power of their abuser (Plummer \& Cossins, 2018), and sometimes manifested in the response of running away. For Mendel (1995, p.214), males who have been abused and later perpetrate CSA are distinguished from those who do not abuse, by their inability to "work through" the trauma experienced. It appears that the men in this study were not afforded the opportunity to do this. Their early sexual trauma has been unheard - even where it was 
Male child sexual abusers telling and not telling of sexual abuse experienced in childhood

disclosed in childhood - and this may have placed them at increased risk of becoming abusers (Craissati et al., 2002). This warrants further examination.

\section{Limitations}

There are a number of limitations to this research, not least, the emphasis on offenders' selfreporting of CSA. Giving sexual offenders a voice requires challenging traditional assumptions that they are devious and manipulative, and "unreliable in relation to their selfreport" (Hackett \& Masson, 2006, p.184). Some argue that CSA might be reported in order to minimise guilt, or evoke a sympathetic response (Simons, Wurtele, \& Heil, 2002). Yet others (Weeks \& Widom, 1998) note that under-reporting of CSA is more likely, with perpetrators fearful of presenting as vulnerable. It did not appear that any of the men who reported CSA at interview did so in order to elicit sympathy or advantage. Rather, they were more likely to present as reluctant to discuss their childhood experiences. Of course, the experiences of incarcerated offenders with a history of CSA may not be typical of all men with a CSA history, but they do illustrate aspects of the disclosure process which are likely to be of wider relevance. The research is also limited by the small sample size and its retrospective design, resulting in the possible reinterpretation of events over time (Collin-Vezina et al., 2015). Notwithstanding such limitations, this research makes a contribution to the knowledge base on the sexual abuse of males, and to further understanding of the complex and individual nature of disclosure (Durham, 2003), due to its focus on the stories (Plummer, 1995) of abusive men: a voice often absent from the research evidence.

\section{Implications of the research}

The sexual abuse experienced by males is often misunderstood, trivialised and denied (Spiegel, 2003). It is crucial that this is addressed. Males experience obstacles to disclosure 
Male child sexual abusers telling and not telling of sexual abuse experienced in childhood

which differ to females, mainly as a result of stereotypical notions of masculinity (Dorahy \& Clearwater, 2012). Males who have sexually offended against children have to further contend with perceptions of them as demons (Waldram, 2007), not victims, and their disclosure stories have remained unheard. Moreover, while organisations in the UK and elsewhere provide welcome support to male survivors of CSA, this is a resource not generally available to those who have abused. Although CSA has been the subject of increasing academic and media attention in recent years, "multiple barriers" which inhibit telling, persist (Collin-Vezina et al., 2015, p.132). Such "barriers" are of relevance to the general population and also to the abusive men in this study. If telling is to be facilitated and the harm inflicted by CSA curtailed, it is crucial that future research focuses on the many "roadblocks to disclosure" (Collin-Vezina et al., 2015, p.133) which remain evident across all abused populations, and that there is recognition of the need for a supportive response to telling (Elliott \& Carnes, 2001).

Childhood experiences have the potential to profoundly impact on future behavior (Garrett, 2010). While much research has focused on the extent to which experiencing CSA may play a role in subsequent sexual offending against children (Seto, 2008) - or the sexually abused-sexual abuser hypothesis (Jespersen et al., 2009) - the evidence remains conflicting (Plummer \& Cossins, 2018). Listening to those who have sexually abused does not equate to an acceptance of, or collusion with sexual abuse (Hackett \& Masson, 2006). Of course, their voices may be unpalatable to many (Elliot, Browne, \& Kilcoyne, 1995). Yet, their stories should not be overlooked, as they may shed some light on offenders' own abusiveness and their transition from victim to perpetrator. Offenders' experiences as victims cannot be discounted. Indeed, on a practice level, it is essential that "the offender is heard as a victim in his own right" (Craissati et al., 2002, p.236), so that the "capacity to develop appropriate victim empathy" is enabled. Further research focusing on offenders' accounts of their own 
Male child sexual abusers telling and not telling of sexual abuse experienced in childhood

abuse and the extent to which that might have contributed to their offending, will inform more effective intervention allowing offenders to move towards desistence (Ward, 2014), and contribute to improved safeguarding and preventive measures.

\section{Word count: 6,193}

\section{References}

Alaggia, R. (2004). Many ways of telling: expanding conceptualizations of child sexual abuse disclosure. Child Abuse \& Neglect, 28, 1213-1227. doi: 10.1016/.j.chiabu.2004.03.016

Alaggia, R. \& Kirshenbaum, S. (2005). Speaking the unspeakable: Examining the impact of family dynamics on child sexual abuse disclosure. Families in Society, 86, 227-234. doi: 10. 1606/1044-3894.2457

Allnock, D. (2010). Children and young people disclosing sexual abuse: An introduction to the research. Retrieved from http://www.childmatters.org.nz/file/Diploma$\underline{\text { Readings/Block-2/Sexual-Abuse/3.4-children-and-young-people-disclosing-sexual- }}$ abuse-updated.pdf.

Anderson, T.H. (2011). Against the wind: male victimization and the ideal of manliness, Journal of Social Work. 13, 231-347. doi:10.1177/1468017311410002

Barter, C. (2003). Abuse of children in residential care. London: NSPCC.

Bryman, A. (2008). (3 ${ }^{\text {rd }}$ ed.) Social Research Methods, Oxford: Oxford University Press. Children's Commissioner for England (2015). Protecting Children from Harm: A critical assessment of child sexual abuse in the family network for England and priorities for action. Retrieved from https://www.childrenscommissioner.gov.uk/publication/protecting-children-fromharm/

Collin-Vezina, D., De la Sablonniere, M., Palmer, A. \& Milne, L. (2015). A preliminary 
Male child sexual abusers telling and not telling of sexual abuse experienced in childhood

mapping of individual, relational and social factors that impede disclosure of childhood sexual abuse. Child Abuse \& Neglect, 43, 123-134. doi: 10.1016/j.chiabu.2015.03.010

Colton, M., Roberts, S. \& Vanstone, M. (2012). Learning lessons from men who have sexually abused children. The Howard Journal of Criminal Justice, 51, 79-93. doi: 10.1111/j.1468-2311.2011.00682.x

Craissati, J., McClurg, G. \& Browne, K. (2002). Characteristics of Perpetrators of Child Sexual Abuse Who Have Been Sexually Victimized as Children. Sexual Abuse: A Journal of Research and Treatment, 14, 225-239. doi: 10.1177/107906320210400303

Deering, R. \& Mellor, D. (2011). An Exploratory Study of the Self-Reported Impact of Female-Perpetrated Childhood Sexual Abuse. Journal of Child Sexual Abuse, 20, 5876. doi: $10.1080 / 10538712.2011 .539964$

Denov, M. (2004). The long-term effects of child sexual abuse by female perpetrators: a qualitative study of male and female victims. Journal of Interpersonal Violence, 19, 1137-1156. doi: 10.1177/0886260504269093

Denov, M. (2003). 'To a safer place? Victims of sexual abuse by females and their disclosures to professionals'. Child Abuse \& Neglect, 27, 47-61. doi: 10.1016/s01452134(02)00509-4

Dodsworth, J. (2014). Sexual Exploitation, Selling and Swapping Sex: Victimhood and Agency. Child Abuse Review, 23, 185-199. doi: 10.1002/car.2282

Donalek, J.G. (2001). First incest disclosure. Issues in Mental Health Nursing, 22, 573-591. doi: 10.1080/016128401750364129

Dorahy, M.J. \& Clearwater, K. (2012). Shame and guilt in men exposed to childhood sexual abuse: A qualitative investigation. Journal of Child Sexual Abuse, 21, 155-175. doi: $10.1080 / 10538712.2012 .659803$ 
Male child sexual abusers telling and not telling of sexual abuse experienced in childhood

Durham, A. (2003). Young Men Living Through and with Child Sexual Abuse: A

Practitioner Research Study. British Journal of Social Work, 33, 309-323. doi: 10.1093/bjsw.33.3.309

Easton, S.D. (2013). Disclosure of Child Sexual Abuse Among Adult Male Survivors. Clinical Social Work Journal. 41, 344-355. doi: 10.1007/s10615-012-0420-3

Easton, S.D., Saltzman, L.Y. \& Willis, D.G. (2014). "Would You Tell Under Circumstances Like That?": Barriers to Disclosure of Child Sexual Abuse for Men. Psychology of Men \& Masculinity, 15, 460-469. doi: 10.1037/a0034223

Elliott, A.N. \& Carnes, C.N. (2001). Reactions of Nonoffending Parents to the Sexual Abuse of their Child: A Review of the Literature. Child Maltreatment, 6, 314-331. doi: $10.1177 / 1077559501006004005$

Elliott, M. (1993). (Ed.). Female Sexual Abuse of Children: The Ultimate Taboo. UK: Longman.

Elliot, M., Browne, K. \& Kilcoyne, J. (1995). Child Sexual Abuse Prevention: What Offenders Tell Us, Child Abuse \& Neglect, 19, 579-594. doi: 10.1016/01452134(95)00017-3

Finkelhor, D. (1986). A sourcebook on child sexual abuse. London: Sage.

Finkelhor, D. (1984). Child Sexual Abuse: New Theory \& Research. New York: The Free Press.

Finkelhor, D. \& Browne, A. (1985). The Traumatic Impact of Child Sexual Abuse: A Conceptualization. American Journal of Orthopsychiatry, 55, 530-541. doi: 10.1111/j.1939-0025.1985.tb02703.x

Finkelhor, D., Meyer Williams, L. \& Burns, N. (1988). Nursery Crimes: Sexual Abuse in Day Care. London: Sage.

Fontes, L.A. \& Plummer, C. (2010). Cultural Issues in Disclosures of Child Sexual Abuse. 
Male child sexual abusers telling and not telling of sexual abuse experienced in childhood

Journal of Child Sexual Abuse, 19, 491-518. doi: 10.1080/10538712.2010.512520

Gagnier, C. \& Collin-Vezina, D. (2016). The Disclosure Experiences of Male Child Sexual Abuse Survivors. Journal of Child Sexual Abuse, 25, 221-241. doi: $10.1080 / 10538712.2016 .1124308$

Garrett, L.H. (2010). Childhood Experiences of Incarcerated Male Child Sexual Abusers. Issues in Mental Health Nursing, 31, 679-685. doi: 10.3109/01612840.2010.496138

Gilligan, P. \& Akhtar, S. (2006). Cultural Barriers to the Disclosure of Child Sexual Abuse in Asian Communities: Listening to What Women Say. British Journal of Social Work, 36, 1361-1377. doi: 10.1093/bjsw/bch309

Goodman-Brown, T.B., Edelstein, R.S., Goodman, G.S., Jones, D.P.H. \& Gordon, D.S. (2003). 'Why children tell: a model of children's disclosure of sexual abuse'. Child Abuse \& Neglect, 27, 525-540. doi: 10.1016/s0145-2134(03)00037-1

Hackett, S. \& Masson, H. (2006). Young People who have Sexually Abused: What do they (and their parents) want from Professionals? Children \& Society, 20, 183-195. doi: 10.1002/CHI.873

Hunter, M. (1990). Abused boys: the neglected victims of sexual abuse. Lexington, MA, USA: Lexington Books.

Hunter, S.V. (2015). Perceptions of the Role of Mothers in the Disclosure and NonDisclosure of Child Sexual Abuse: A Qualitative Study. Journal of Child Sexual Abuse, 24, 887907. doi: 10.1080/10538712.2015.1092005

Hunter, S.V. (2011). Disclosure of child sexual abuse as a life-long process: Implications for health professionals. Australian and New Zealand Journal of Family Therapy (ANZJFT), 32, 159-172. doi: 10.1375/anft.32.2.159

Isely, P.J., Isely, P., Freiburger, J. \& McMackin, R. (2008). In their own voices: A qualitative 
Male child sexual abusers telling and not telling of sexual abuse experienced in childhood

study of men abused as children by catholic clergy. Journal of Child Sexual Abuse, 17, 201-215. doi: 10.1080/10538710802329668

Jensen, T.K., Gulbrandsen, W., Mossige, S., Reichelt, S. \& Tjersland, O.A. (2005). Reporting possible sexual abuse: A qualitative study on children's perspectives and the context for disclosure. Child Abuse \& Neglect, 29, 1395-1413. doi: 10.1016/j.chiabu.2005.07.004

Jespersen, A.F., Lalumiere, M.L. \& Seto, M.C. (2009). Sexual abuse history among adult sex offenders and non-sex-offenders: A meta-analysis. Child Abuse \& Neglect, 33, 179192. doi: http//:dx.doi.org./10.1016/j.chiabu.2008.07.004

Jonzon, E. \& Lindblad, F. (2004). Disclosure, reactions, and social support: Findings from a sample of adult victims of child sexual abuse. Child Maltreatment, 9, 190-200. doi: $10.1177 / 1077559504264263$

Lambie, I. \& Johnson, E. (2016). "I Couldn't Do It to a Kid Knowing What it Did to Me": The Narratives of Male Sexual Abuse Victims' Resiliency to Sexually Offending. International Journal of Offender Therapy and Comparative Criminology, 60, 897918. doi: 10.1177/0306624X14567664

Lincoln, S.Y. \& Guba, E.G. (1985). Naturalistic Inquiry. Thousand Oaks, CA: Sage.

Lovett, B.B. (2004). Child sexual abuse disclosure: maternal response and other variables impacting the victim. Child and Adolescent Social Work, 21, 355-371. doi: 10.1023/B:CASW.0000035221.78729.d6

McElvaney, R. (2015). Disclosure of Child Sexual Abuse: Delays, Non-disclosure and Partial Disclosure. What the Research Tells Us and Implications for Practice. Child Abuse Review, 24, 159-169. doi: 10.1002/car.2280

McGregor, K., Julich, S., Glover, M. \& Gautam, J. (2010). Health Professionals’ Responses to Disclosure of Child Sexual Abuse History: Female Child Sexual Abuse Survivors' Experiences. Journal of Child Sexual Abuse, 19, 239-254. doi: 1080/10538711003789015 
Male child sexual abusers telling and not telling of sexual abuse experienced in childhood

McGuffey, C. (2008). "Saving masculinity": Gender reaffirmation, sexuality, race, and parental responses to male child sexual abuse. Social Problems, 55, 216-237. doi: 10.1525/sp.2008.55.2.216

Mellor, D. \& Deering, R. (2010). Professional responses and attitudes toward female perpetrated child sexual abuse: A study of psychologists, psychiatrists, probationary psychologists and child protection workers. Psychology, Crime \& Law, 16, 415-438. doi: $10.1080 / 10683160902776850$

Mendel, M.P. (1995). The Male Survivor: The Impact of Sexual Abuse. London: Sage.

Miles, M. \& Huberman, A. (1994). Qualitative Data Analysis. Thousand Oaks, CA: Sage.

Oaksford, K. \& Frude, N. (2003). The Process of Coping Following Child Sexual Abuse: A Qualitative Study. Journal of Child Sexual Abuse, 12, 41-72. doi: 10.1300/J070v12n02_03

Ogloff, J.R.P., Cutajar, M.C., Mann, E. \& Mullen, P. (2012). Child sexual abuse and subsequent offending and victimisation: A 45 year follow-up study. Trends \& Issues in Crime \& Criminal Justice No. 440, Canberra: Australian Institute of Criminology.

O’Leary, P.J. \& Barber, J. (2008). Gender differences in silencing following childhood sexual abuse, Journal of Child Sexual Abuse. 17, 133-143. doi: $10.1080 / 10538710801916416$

O'Leary, P., Coohey, C. \& Easton, S.D. (2010). The effect of severe child sexual abuse and disclosure on mental health during adulthood. Journal of Child Sexual Abuse, 19, 275-289. doi: 10.1080/10538711003781251

Paine, M.L. \& Hansen, D.J. (2002). Factors influencing children to self-disclose sexual abuse. Clinical Psychology Review, 22, 271-295.doi: 10.1016/S0272-7358(01)000915

Pintello, D. \& Zuravin, S. (2001). Intrafamilial Child Sexual Abuse: Predictors of 
Male child sexual abusers telling and not telling of sexual abuse experienced in childhood

Postdisclosure Maternal Belief and Protective Action. Child Maltreatment, 6, 344352. doi: $10.1177 / 1077559501006004007$

Plummer, K. (1995). Telling sexual stories: Power, change and social worlds. London:

Routledge.

Plummer, M. \& Cossins, A. (2018). The Cycle of Abuse: When Victims Become Offenders. Trauma, Violence \& Abuse, 19, 286 - 304. doi: 10.1177/1524838016659487

Priebe, G. \& Svedin, C.G. (2008). Child sexual abuse is largely hidden from the adult society. An epidemiological study of adolescents' disclosures. Child Abuse \& Neglect, 32, 1095-1108. doi: 10.1016/j.chiabu.2008.04.001

Reitsema, A.M. \& Grietens, H. (2016). Is Anybody Listening?: The Literature on the Dialogical Process of Child Sexual Abuse Disclosure Reviewed. Trauma, Violence, \& Abuse, 17, 330-340. doi: 10/11771524838015584368

Ressel, M., Lyons, J. \& Romano, E. (2018). Abuse Characteristics, Multiple Victimisationand Resilience among Young Adult Males with Histories of Childhood Sexual Abuse. Child Abuse Review, 27, 239-253. doi: 10.1002/car.2508

Roberts, S. (2017). Experiencing sexual victimisation in childhood: meaning and impactthe perspectives of child sexual abusers. (Doctoral dissertation, Swansea University, Swansea, UK). Retrieved from http://cronfa.swan.ac.uk

Roberts, S. \& Vanstone, M. (2014). A Child Sexual Abuse Research Project: A Brief Endnote. Journal of Child Sexual Abuse, 23, 745-754. doi: $10.1080 / 10538712.2014 .934416$

Romano, E., Moorman, J. Ressel, M. \& Lyons, J. (2019). Men with childhood sexual abuse histories: Disclosure experiences and links with mental health. Child Abuse \& Neglect, 89, 212-224. doi: 10/1016.j.chiabu.2018.12.010

Seto, M.C. (2008). Paedophilia and sexual offending against children: theory, assessment, 
Male child sexual abusers telling and not telling of sexual abuse experienced in childhood

and intervention. Washington, DC: American Psychological Association.

Sgroi, S.M. (1982). Handbook of clinical intervention in child sexual abuse, Lexington, MA: Lexington Books.

Simons, D., Wurtele, S.K. \& Heil, P. (2002). Childhood Victimisation and Lack of Empathy as Predictors of Sexual Offending Against Women and Children, Journal of Interpersonal Violence, 17, 1291-1307. doi: 10.1177/088626002237857

Smallbone, S. W. \& Wortley, R.K. (2001). Child Sexual Abuse: Offender Characteristics and Modus Operandi. No. 193, Trends \& Issues in Crime and Criminal Justice. Australian Institute of Criminology, Canberra. Retrieved from http://www.aic.gov.au/media_library/publications

Smith, N., Dogaru, C. \& Ellis, F. (2015). Hear Me. Believe Me. Respect Me. A survey of adult survivors of child sexual abuse and their experiences of support services, University Campus Suffolk and Survivors in Transition. Retrieved from http://cdn.basw.co.uk/upload/basw_122305-1.pdf

Sorsoli, L., Kia-Keating, M. \& Grossman, F.K. (2008). “I Keep That Hush-Hush”: Male Survivors of Sexual Abuse and the Challenges of Disclosure. Journal of Counselling Psychology, 55, 333-345. doi: 10.1037/0022-0167.55.3.333

Spiegel, J. (2003). Sexual Abuse of Males: The SAM Model of Theory and Practice. New York: Brunner-Routledge.

Staller, K.M. \& Nelson-Gardell, D. (2006). “A burden in your heart”: Lessons of disclosure from female preadolescent and adolescent survivors of sexual abuse. Child Abuse \& Neglect, 29, 1415-1432. doi: 10.1016/j.chiabu.2005.06.007

Stathopoulos, M. (2012). Sibling sexual abuse. Australian Centre for the Study of Sexual Assault. Retrieved from http://www.aifs.gov.au/acssa/pubs/researchsummary

Strauss, A.L. (1987) Qualitative analysis for social scientists. Retrieved from 
Male child sexual abusers telling and not telling of sexual abuse experienced in childhood

https://www.cambridge.org/core/books/qualitative-analysis-for-social$\underline{\text { scientists/1EBB3B490B28C39D7A33EB12A58B211B }}$

Summit, R.C. (1983). The Child Sexual Abuse Accommodation Syndrome. Child Abuse \& Neglect, 7, 177-193. doi: 10.1016/0145-2134(83)90070-4

Tener, D. \& Murphy, S. B. (2015). Adult Disclosure of Child Sexual Abuse: A Literature Review. Trauma, Violence \& Abuse, 16, 391-400. doi: 10.11771524838014537906

Ullman, S.E. (2003). Social reactions to child sexual abuse disclosures: A critical review. Journal of Child Sexual Abuse, 12, 89-121. doi: 10.1300/J070v12n01_05

van Toledo, A. \& Seymour, F. (2016). Caregiver Needs Following Disclosure of Child Sexual Abuse. Journal of Child Sexual Abuse, 25, 403-414. doi: $10.1080 / 10538712.2016 .1156206$

Waldram, J.B. (2007). Everybody Has a Story: Listening to Imprisoned Sexual Offenders. Qualitative Health Research. 17, 963-970. doi: 10.1177/1049732307306014

Ward, T. (2014). The explanation of sexual offending: from single factor theories to integrative pluralism. Journal of Sexual Aggression, 20, 130-141. doi: $10.1080 / 13552600.2013 .870242$

Weeks, R. \& Widom, C. (1998). Self-reports of early childhood victimization among incarcerated adult male felons. Journal of Interpersonal Violence, 13, 346-361. doi: $10.1177 / 088626098013003003$

World Health Organisation. (2017). Responding to children and adolescents who have been sexually abused. Retrieved from http://www.who.int 
Male child sexual abusers telling and not telling of sexual abuse experienced in childhood

Table 1: Disclosing child sexual abuse: when and to whom?

$\mathrm{N}=11$

\begin{tabular}{|c|c|c|c|c|}
\hline Pseudonym + Age & $\begin{array}{l}\text { Disclosed as } \\
\text { child? }\end{array}$ & $\begin{array}{l}\text { Disclosed as } \\
\text { adult? }\end{array}$ & Abused by? & Disclosed to? \\
\hline Alan (36) & Yes & / & $\begin{array}{l}\text { E/F: Father's } \\
\text { friend }\end{array}$ & Father \\
\hline *Brian (57) & $\begin{array}{l}\text { Yes } \\
\text { Yes }\end{array}$ & / & $\begin{array}{l}\text { (1)E/F: Neighbour } \\
\text { (2)E/F: Hotel staff }\end{array}$ & $\begin{array}{l}\text { (1)Mother } \\
\text { (2)Hotel } \\
\text { management }\end{array}$ \\
\hline *Oliver (37) & $\begin{array}{l}\text { Yes } \\
\text { Yes } \\
\text { (Did not disclose } \\
\text { sibling abuse) }\end{array}$ & / & $\begin{array}{l}\text { (1)E/F: Family } \\
\text { friend } \\
\text { (2)E/F: } \\
\text { Residential care } \\
\text { staff }\end{array}$ & $\begin{array}{l}\text { (1)Mother } \\
\text { (2)Residential } \\
\text { care staff }\end{array}$ \\
\hline *Francis (35) & $\begin{array}{l}\text { Yes } \\
\text { (Did not disclose } \\
\text { abuse by youth } \\
\text { worker) }\end{array}$ & / & I/F: Brother & Parents \\
\hline Andrew (51) & Yes & I & I/F: Grandmother & Parents \\
\hline *Frank (55) & $\begin{array}{l}\text { Yes } \\
\text { (Did not disclose } \\
\text { female- } \\
\text { perpetrated } \\
\text { abuse) }\end{array}$ & / & $\begin{array}{l}\text { E/F: Institutional } \\
\text { abuse }\end{array}$ & $\begin{array}{l}\text { Residential care } \\
\text { staff }\end{array}$ \\
\hline William (67) & No & Yes & E/F: Roomer & Prison staff \\
\hline Ellis (23) & No & Yes & I/F: Uncle & Prison staff \\
\hline Edward (33) & No & Yes & E/F: Family friend & Prison staff \\
\hline Luke (57) & No & Yes & $\begin{array}{l}\text { I/F: Male family } \\
\text { member - } \\
\text { identity not } \\
\text { disclosed }\end{array}$ & Prison staff \\
\hline Bob* (45) & $\begin{array}{l}\text { No } \\
\text { (Did not disclose } \\
\text { abuse by youth } \\
\text { worker) }\end{array}$ & Yes & (1)E/F: Neighbour & $\begin{array}{l}\text { (1)Family } \\
\text { members (since } \\
\text { imprisonment) }\end{array}$ \\
\hline
\end{tabular}

Key:

Perpetrators male unless otherwise specified

* Denotes re-victimization - some men appear in both Table 1 and Table 2

I/F: intra-familial

E/F: extra-familial 
Male child sexual abusers telling and not telling of sexual abuse experienced in childhood

Table 2: Not telling in childhood: why?

$\mathbf{N}=11$

\begin{tabular}{|c|c|c|}
\hline Pseudonym + Age & Abuse experienced? & $\begin{array}{l}\text { Reason/s for not telling } \\
\text { in childhood? }\end{array}$ \\
\hline Neil (63) & I/F: Uncle & $\begin{array}{l}\text { Fear of violence from } \\
\text { perpetrator }\end{array}$ \\
\hline Donald (44) & I/F: Father & $\begin{array}{l}\text { Fear of violence from } \\
\text { perpetrator }\end{array}$ \\
\hline Steven (45) & $\begin{array}{l}\text { E/F: Multiple } \\
\text { perpetrators }\end{array}$ & $\begin{array}{l}\text { Fear of violence from } \\
\text { non-abusing father }+ \\
\text { Abusers' message would } \\
\text { not be believed }\end{array}$ \\
\hline Barry (41) & $\begin{array}{l}\text { E/F: Multiple } \\
\text { perpetrators }\end{array}$ & Sense of shame \\
\hline *John (41) & $\begin{array}{l}\text { E/F: Residential care } \\
\text { worker } \\
\text { I/F: Brother }\end{array}$ & $\begin{array}{l}\text { Fear of not being believed } \\
\text { Not specified }\end{array}$ \\
\hline *Oliver (37) & I/F: Brother & Not specified \\
\hline Bill (34) & I/F: Mother & $\begin{array}{l}\text { Fear of consequences for } \\
\text { family }\end{array}$ \\
\hline Gareth (25) & I/F: Sister & Sense of isolation \\
\hline *Frank (55) & $\begin{array}{l}\text { E/F: Female family } \\
\text { friend }\end{array}$ & $\begin{array}{l}\text { Mixture of fear }+ \\
\text { excitement }\end{array}$ \\
\hline *Bob (45) & $\begin{array}{l}\text { (1)E/F: Neighbour } \\
\text { (2)E/F: Youth worker }\end{array}$ & $\begin{array}{l}\text { Positive relationship with } \\
\text { perpetrator } \\
\text { Not specified }\end{array}$ \\
\hline${ }^{*}$ Francis (35) & E/F: Youth worker & Not specified \\
\hline \multicolumn{3}{|c|}{$\begin{array}{l}\text { Key: } \\
\text { Perpetrators male unless otherwise specified } \\
\text { *Denotes re-victimization }-4 \text { men appear in both Table } 1 \text { and Table } 2 \\
\text { I/F: intra-familial } \\
\text { E/F: extra-familial }\end{array}$} \\
\hline
\end{tabular}

